\title{
Rekonstrukce a revitalizace městského muzea v Hořicích
}

Oldřiška Tomíčková a kol.

\section{Reconstruction and Revitalization of the Municipal Museum in Hořice}

Historie hořického muzea sahá až do sklonku 19. století. Jeho předchůdce Archeologický a musejní spolek - byl založen již v r. 1887. V roce 1904 při něm vzniká jako odnož Podkrkonošské průmyslové museum, které se o rok později osamostatňuje. Jeho cílem byla podpora některých místních řemeslných oborů (výroba dřevěných hraček, skleněných perlí a brousků $\mathrm{v}$ místního pískovce). V r. 1908 byla při průmyslovém muzeu založena Galerie plastik jako jedna z našich prvních venkovských galerií. Její existence byla od samého počátku úzce propojena se zdejší sochařskou školou (založena r. 1884) a osobnostmi na ní působícími. V r. 1937 se archeologický spolek mění na Vlastivědné museum okresu hořického. V r. 1946 zaniká průmyslové muzeum a jeho sbírky a knihovna jsou připojeny ke sbírkám vlastivědného muzea. Připojena byla také Galerie plastik, $\mathrm{v}$ té době umístěná $\mathrm{v}$ sochařské škole. V r. 1951 je muzeum zestátněno a název změněn na Okresní vlastivědné museum. Další změna přichází v r. 1960 po územní reorganizaci, kdy Hořice přestávají být sídlem okresu a muzeum se mění na městské. V současné době je Městské muzeum a galerie, jak zní oficiální název, organizační složkou Města Hořice bez právní subjektivity. Jde však o poměrně rozsáhlou organizaci, $\mathrm{k}$ níž náleží městské muzeum, Galerie plastik, Masarykova věž samostatnosti a od r. 2018 také Museum Czech Road Racing, zaměřené na historii zdejších slavných motocyklových závodů, které je umístěno $\mathrm{v}$ místním zámku. Hořické muzeum má tedy ve své náplni poměrně široké spektrum témat, která sleduje a dokumentuje, a samozřejmě kromě sbírek i péči o řadu budov. Zde se však zaměříme pouze na hlavní muzejní budovu.
Městské muzeum sídlí od r. 1942 v krásné novorenesanční budově čp. 160 na náměstí Jiřího z Poděbrad. Dưm byl postaven v r. 1877 podnikatelem Václavem Tomáškem podle plánů zdejšího stavitele Františka Karažeje. Po krachu bašnického cukrovaru v r. 1883 přišel Tomášek o veškerý majetek - tři domy a mlýn. Dům čp. 160 byl prodán ve veřejné dražbě a několikrát změnil majitele, až jej v r. 1908 koupil hořický okres. Od té doby byl nazýván Okresní dům, jak dodnes dokládá kamenný nápis na jeho římse. Byly zde umístěny kanceláře a zasedací síň okresní samosprávy. Po obnovení politického okresu v Hořicích v r. 1935 se rozhodlo postavit pro jeho potřeby novou administrativní budovu, do níž se úřadovny v r. 1942 přestěhovaly. V téže době získalo uvolněnou budovu čp. 160 muzeum, dosud živořící $\mathrm{v}$ jedné $\mathrm{z}$ místních obecných škol. Téměř okamžitě byly umístěny v 1. poschodí stálé expozice kvůli obavě, aby budovu nezabrali Němci. V přízemí se nacházela kancelář s knihovnou a výstavní sín. Depozitáře byly umístěny ve dvou nádvorních objektech, které se však nenacházely v dobrém technickém stavu. V 50. letech získalo hořické muzeum odkazem spisovatele Eduarda Štorcha jeho pozůstalost, knihovnu a výnosy z autorských práv. Z nich pak byla koncem 60 . let přistavěna do dvora velká moderní výstavní síň se stropním světlem, která posléze dostala název Štorchova. Zdálo se, že situace hořického muzea je uspokojivě vyřešena, ale jen na krátký čas. Počátkem 70. let se zhoršil technický stav depozitářů natolik, že musely být sbírky vystěhovány do hlavní budovy, a tím zanikly stálé expozice. Tento neutěšený stav se protáhl na několik desetiletí, kdy vzácné sbírkové předměty odpočívaly natěsnány ve skříních
PhDr. Oldřiška Tomíčková Muzeum Hořice tomickova@muzeum.horice. org 
a krabicích $\mathrm{v} 1$. patře a $\mathrm{v}$ podkroví a mohly být prezentovány jen při krátkodobých výstavách. Zub času si zahlodal i na stavu hlavní muzejní budovy, kde jakoby se zastavil čas a vše pomalu dosluhovalo.

Naděje na vyřešení této neutěšené situace přichází s projektem Cesta kamene, který byl podán do výzvy Prioritní osy 2 programu Interreg V-A Česká republika Polsko. Hlavními partnery projektu, který měl zvýšit turistickou atraktivitu společného př́hraničního regionu, byla města Hořice a Strzegom v Dolním Slezsku, obě známá těžbou a zpracováním kamene: pískovce na české straně a žuly na straně polské. Do projektu se dále zapojilo sdružení Podzvičinsko a města Świdnica a Dobromierz. Projekt získal v rámci hodnocení nejvyšší počet bodů. Vedle propagace zmíněného regionu a přeznačení turistických tras a okruhů byla klíčovou aktivitou na české straně rekonstrukce a revitalizace budovy městského muzea v Hořicích. Radostná zpráva o úspěchu žádosti přišla v prosinci 2016 a od ledna do března následujícího roku bylo nutné zabalit a přestěhovat všechny sbírkové předměty (přibližně 40000 kusů) do náhradních prostor $\mathrm{v}$ budově bývalého gymnázia v Husově ulici. Zde jsou muzejní depozitáře umístěny dodnes.

Nová stálá expozice městského muzea v Hořicích spolu s celkovou rekonstrukcí objektu muzea patří mezi nejvýznamnější kulturní počiny města Hořice v novodobém období. Expozice s názvem „Od kamene k soše" mapuje kámen (pískovec) jako uměleckořemeslný prvek, který má v Hořicích bohatou historii. Město a okolí je známo těžbou kvalitního pískovce pro stavební a umělecké zpracování. Ne nadarmo v Hořicích nalezneme světoznámé sochařské symposium a sochařský park s více než 130 plastikami od 60. let 20. století do současnosti nebo jednu z nejvýznamnějších sochařsko-kamenických škol ve střední Evropě. Expozice „Od kamene k soše" v hořickém muzeu tak zcela přirozeně vychází z historické a kulturní tradice města a svým charakterem a uměleckým zpracováním nabízí zcela unikátní zážitek v rámci celé České republiky.
Vysoká úroveň prezentace a zpřístupnění hodnot spojených s kulturou kamene vychází ze třech základních komponent. Zaprvé jde o jedinečné propojení ducha expozice s objektem muzea, který samotný představuje expozičně hodnotný prvek. Exteriér objektu vynikne díky nově zrekonstruované novoklasicistní pískovcové fasádě s historizujícími prvky (sloupoví, balustráda apod.), zatímco interiéru vévodí reprezentativní sloupová síň a schodiště. Stavebně-řemeslné prvky tvarované $z$ pískovce dokreslují atmosféru objektu a ideálně ladí s expozicí o kameni jako takovém. Druhým komponentem je samotné interiérové řešení expozic dle návrhu Ing. arch. Aleše Valáška, které přináší velmi komorní a přitom moderní přístup $\mathrm{k}$ expozicím, založený především na stabilizaci světelných podmínek tak, aby daly plně vyniknout jednotlivým exponátům nezávisle na denní době, či interaktivních prvcích, oslovujících širší smysly návštěvníkư. Třetí komponentu pak vytváŕí citlivé včlenění multimediálních prvků do expozic, at již prostřednictvím televizních panelů, nebo dotykových informačních, vzdělávacích či herních obrazovek. Celkově můžeme říci, že efekt samotné prezentace kultury kamene zesiluje umně zvládnuté propojení moderních výstavních prvků a prístupů se šetrností k historickému odkazu objektu. V této souvislosti je třeba zmínit maximální důraz, který kladli jak autor architektonicko-dispozičního řešení Ing. arch Martin Pour, tak hlavní inženýr projektu Ing. arch. Jiří Zídka na udržení historické a památkové autentičnosti objektu. Stálá expozice "Od kamene k soše “ se nachází ve dvou výstavních sálech. Místnost $v$ prrízemí budovy je rozčleněna do dvou tematických částí. Přri vstupu se nachází část věnovaná geologii a použití pískovce pro výrobu předmětů denní potřeby. Druhá část je věnována pískovci a jeho roli v architektuře, umění a řemeslech města Hořice. Druhá část expozice se nachází v 2. poschodí a cílí na reprodukční techniky a přenos plastiky z modelu do finálního materiálu. Mapuje různé druhy plastik (např. plastika pro sepulkrální 
architekturu, pomníky apod.). Obě expoziční místnosti mají charakter potemnělého prostoru, ve kterém jsou světlem zvýrazněny jednotlivé exponáty. Cílem bylo místnosti rozčlenit tak, aby je nešlo zběžně přejet pohledem, ale aby se pomocí mobiliáře dosáhlo rozčlenění prostoru, jenž nabídne návštěvníkovi zajímavou perspektivu, nevšední úhel pohledu na exponáty a dostatečný odstup od exponátů podle jejich velikosti. Dalším kritériem bylo exponáty vystavit tak, aby pohled na ně alespoň částečně suploval podmínky, jakým způsobem by na danou plastiku diváci nazírali $\mathrm{v}$ její původních podmínkách. $\mathrm{V}$ důsledku tak měla expozice za cíl návštěvníkům nabídnout různorodé zážitky.

Stálá expozice je dále doplněna sochami, bustami a obrazy, které jsou rozmístěny v sloupové síni, na schodišti či na chodbách v 2. poschodí. Jeden z nejvýznamnějších artefaktů představuje nepochybně socha Q. Kociána Šárka, která se nachází v centrální částí sloupové síně a tvoří dominantní pohled $\mathrm{v}$ interiérové části muzea.

Celkovou rekonstrukcí prošla také Štorchova sín a v 2. poschodí vznikl př́ijemný přednáškový sál vybavený moderní audiovizuální technikou i zázemím pro pořádání přednášek, seminářù a konferencí. Může sloužit i jako komornější výstavní prostor. Úpravami prošlo také podkroví, které se využívá především pro pořádání workshopů. Kdysi zpustlý dvůr s ruinami bývalých depozitářu se proměnil v krásné atrium, které $\mathrm{v}$ teplých měsících slouží jako velmi př́jemný prostor pro konání koncertů a jiných kulturních akcí, např. předávání maturitních vysvědčení. Zastřešená část atria bude $\mathrm{v}$ budoucnu využita jako lapidárium. Celý objekt muzea je plně bezbariérový.

Autory libreta expozic jsou zaměstnanci Městského muzea a galerie Hořice: Mgr. Václav Horák, PhDr. Oldřiška Tomíčková, PhDr. Jana Cermanová, Ph.D., Mgr. Jarmila Gregorová a Tomáš Mates.

Autorem interiérového řešení expozic je Ing. arch. Aleš Valášek ve spolupráci s autorem ideje obnovy a architektonicko-dispozičního řešení Ing. arch Martinem Pourem a hlavním inženýrem projektu Ing. arch. Jiřím Zídkou. Dodavatelem interiéru a mobiliáře byla společnost READY INTERIER s.r.o. Hradec Králové. Stavební práce provedla firma MATEX Hradec Králové.

Muzeum bylo slavnostně otevřeno 25. dubna 2019 a jeho expozice i zrekonstruovaná budova se od samého začátku těší zasloužené pozornosti široké veřejnosti. Projekt rekonstrukce muzea a stálá expozice „Od kamene k soše“ byl odměněn několika prestižními cenami. V soutěži Památka roku 2019 v Královéhradeckém kraji získal 1. místo a v celostátním kole téže soutěže 3. prŕíčku. $V$ národní soutěži Gloria musaealis v kategorii Muzejní počin roku byl oceněn 2 . místem. 